\title{
Excess lifetime cancer risk due to natural background radiations of soil in North Kashmir
}

\author{
Mudasir Ashraf, Ph.D. ${ }^{1}$, Mukhtar Thoker, M.Ch ${ }^{2}$, Sajad Ahmad, Ph.D ${ }^{3}$, C. Anu Radha, Ph.D ${ }^{4}$ \\ ${ }^{1,3}$ Research Officer, Senior Research Officer, Deptt. of Radiological Physics and Bio-Engineering, SKIMS \\ ${ }^{2}$ Consultant, Department of Health Services J\&K \\ ${ }^{4}$ Associate Professor, Photonic, Nuclear and Medical physics Division, School of Advanced Sciences, \\ Vellore Institute of Technology, Vellore, Tamil Nadu, India (632014).
}

\section{A B S TRACT}

Background: Long term exposure to environmental radioactivity and the associated external exposure due to gamma emitting radionuclides have serious health effects particularly on cancer risk. Of course, the soil radioactivity depends on the underlying rocks and consequently, the soil type and the geographic conditions.

Objectives: Evaluation of excess life time cancer risk due to natural radioactivity of the soil of surface layer of the Nichahoma lignite belt and the soil of villages surrounding the lignite belt.

Methods: In this particular study, stirring radionuclides of the $\mathrm{Ra}^{226}, \mathrm{Th}^{232}$, and $\mathrm{K}^{40}$ present in the soil samples of the lignite belt and soil of the villages surrounding the lignite belt were measured by using a low-background $\mathrm{Pb}$-shielded gamma spectroscopic counting assembly utilizing $\mathrm{Nal}(\mathrm{TI})$ detector for the measurement and to evaluation the radiation hazard indices and excess life time cancer risk.

Results: The excess life time cancer ranged from $0.65 \times 10^{-3}$ to $0.71 \times 10^{-3}$ (average $\sim 0.68 \times 10^{-3}$ ) for the soil of the lignite belt and from $1.15 \times 10^{-3}$ to $1.34 \times 10^{-3}$ (average $\sim 1.25 \times 10^{-3}$ ) for the soil of the villages surrounding the belt. The correlation analyses, performed between the radium equivalent activity and excess life time cancer risk for the two types of the sample, showed very strong and linear dependence of excess life time cancer risk on radium equivalent activity and measured dose rate for the soil of the lignite belt compared to the soil of the villages surrounding the lignite belt.

Conclusion: Compared to world average, the average value of computed excess life time cancer risk for both the categories of investigated samples in the study was found to be higher than 0.29. JMS 2018:21 (2):101-108

Keyword: Excess life time cancer risk, measured dose rate, radium equivalent activity, correlation analysis, lignite belt.

\section{INTRODUCTION}

Ionizing radiations were discovered by Wilhelm Conrad Roentgen in 1895, and their diagnostic applications were quickly found. The first radiation induced skin cancer was identified in 1902 and the first radiation caused leukemia case found by1911.Various such cases of radiation-induced cancer were found and described over the ensuing decades, radon induced lung cancer in underground metal miners in Eastern Europe, and osteogenic sarcoma in radium dial painters. By1944, based on more formal epidemiological inquiry, an excess of leukemia was reported among radiologists in the United States. ${ }^{[1]}$ By Second World War, there was sufficient understanding of the risks of radiation to motivate a program of protection for workers at the

\section{Correspondence}

Dr. Mudasir Ashraf, Ph.D

Research Officer, Department of Radiological Physics

and Bio-engineering, SKIMS, Srinagar

Email: mudasirashraf8@gmail.com
Manhattan Project in the United States. ${ }^{[2]}$ The characteristic evidence of the carcinogenic nature of ionizing radiations comes from a variety of sources like prolonged and ongoing studies on exposed human populations (Atomic bomb survivors), medical use of ionizing radiation and occupational sources such as Uranium miners, Radium painters. ${ }^{[3]}$

Life originated on the planet, Earth and moved through a regular procession in aradiation field that was more powerful than now. Natural radioactivity is prevalent in the earth's environment and they exist in a variety of physical, biological and environmental formations such as rocks, earth crust, plants, water and air. The concentrations and associated external radiation doses to the general public in different environmental matrices depend on the geology and geographical conditions of such environmental processes, due to weathering, rainfall of a place and other environmental processes, radionuclides in different environmental matrices such as soil and rocks may build up in the sediments and dissolve into drinking water, air we 
breathe, thus lead to human exposure which in turn produce biological damage of the human tissue. The pathways of human exposure include: uptake from tainted water through roots of the plants and trees, inhalation of soil dust, and direct exposure from primitive radionuclides in the indoor and outdoor environments, etc. Research on environmental natural radiations have received universal awareness and lead to widespread study in numerous countries like Spain, Turkey, Nigeria, Malaysia, Iran, and Botswana. The absorbed dose rate in air depends principally on the radionuclide content in the soil, as the largest part of the gamma radiation from the terrestrial and the extra-terrestrial radiations. $^{[4,5]}$

Radiation induced cancer may appear only several years after the radiation exposure. This is time period between the radiation exposure and the manifestation of cancer is called as Latent period, which may lengthen from 10 to 30 years. The risk of causing a particular type of cancer is measured by comparing the number of cancers produced in the irradiated population sample in excess of those expected in the same size of the un-irradiated population sample. Leukemia has the highest risk factor among all cancers, since tissue cells are rapidly dividing. The excess lifetime cancer risk is the likelihood that an individual will develop cancer over his/her lifetime of exposure ${ }^{[6]}$ Our preceding monographs by Mudasir Ashraf et al. ${ }^{[6,7]}$ looked at the radiological health assessment due to gamma radiation levels of natural radioactivity of soil in the vicinity of Nichahoma lignite belt, Kashmir Valley and evaluation of excess life time cancer risk due to natural radioactivity of the Lignite samples of the Nichahoma, lignite belt, North Kashmir, India. This particular study was aimed to focus on the excess life time cancer risk due to natural radioactivity of the soil of surface layer of the Nichahoma lignite belt and the soil of villages surrounding the lignite belt.

\section{METHODS}

\section{Study area}

The study region has quartz veins carrying sulphides of copper and iron with some oxide, carbonates and arsenides. The presence of gold and silver in traces is indicated in the quartz veins carrying sulphides of copper and iron in association with some oxides, carbonates and arsenides in Lolab area of Jammu and Kashmir region. The upper Cambrian region of Kupwara in the northwest Kashmir contains several thick bands of hard and siliceous recrystallised limestone, which is currently being mined and marked as "Kupwara Marble". The estimated lignite reserves at Nichahoma are found to be 80 million tons. This lignite occurs in a track which is around $80 \mathrm{~km}$ long and 16 $\mathrm{km}$ wide that has lignite showing rapid variation in thickness and quality. The geological survey of India proved 4.5 million tons reserves of lignite up to a depth of $36.5 \mathrm{~min}$ Nichahoma area. The Indian Bureau of Mines indicated proven reserves of 7.26 million tons. The quarriable reserves in Nichahoma area were estimated to be 5.26 million tons. ${ }^{[8]}$ The geographic map of the study area is presented in Figure1.

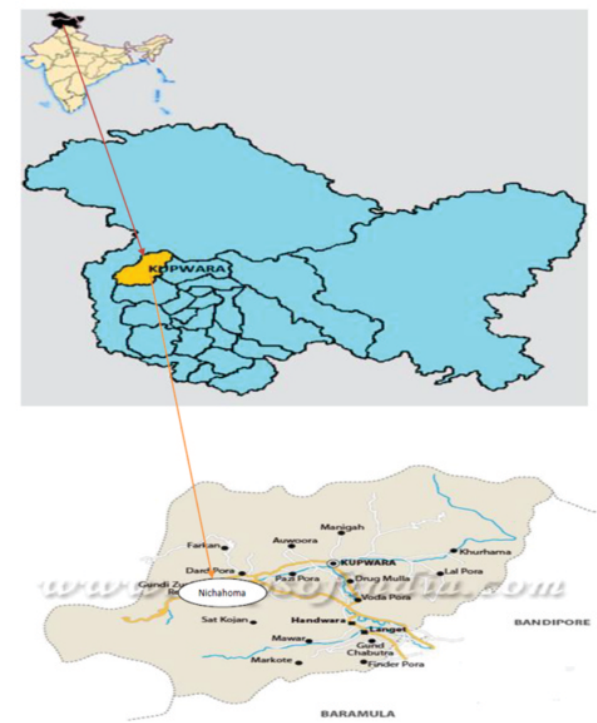

Figure 1: Simplified geological map of the area under study.

\section{Sample Collection}

A total of twenty different samples were collected, the ten different soil samples from the surface of the lignite belt and ten soil samples of from the villages adjacent the lignite belt. After collection, the samples were placed in labeled polyethane bags then transferred to the laboratory for preparation and analysis. The collected samples were processed in accordance with the standard protocols available in the literature. The fundamental aim of the sample processing is to compose the sample look like the standard that was used for efficiency calibration. The sample had been prepared in a manner that the physical properties like dimensions, density and particle size and its distribution of the samples under investigation were similar to that of calibration standards.

The samples were pulverized, heated and dried out in an oven at a temperature of $125^{\circ} \mathrm{C}$ for 24 hours so as to make them moisture free and sieved through a $2 \mathrm{~mm}$ mesh. $1000 \mathrm{~g}$ of samples were filled and sealed in leak-proof, air tight 
PVC merinelli beakers, weighed and stored for a time of four weeks to allow the samples to attain a state of secular equilibrium, where the rate of progeny becomes equal to that of the parent $\left(\mathrm{Ra}^{226}\right.$ and $\left.\mathrm{Th}^{232}\right) .^{[6,7,9]}$

\section{Activity Concentration Measurement}

The radiometric analysis for the radioactivity concentrations of $\mathrm{Ra}^{226}, \mathrm{Th}^{232}$, and $\mathrm{K}^{40}$ in the lignite samples collected from the Nichahoma, lignite belt was performed by using the gamma-ray spectrometer consisting of a $\mathrm{NaI}(\mathrm{Tl})$ detector (crystal size $40.0 \mathrm{~mm}$ x $60.0 \mathrm{~mm}$ ) connected to 1024 channel multichannel analyser (MCA). Before measurement, the samples were pulverized, heated and dried out in an oven at a temperature of $125^{\circ} \mathrm{C}$ for 24 hours so as to make them moisture and sieved through a $2 \mathrm{~mm}$ mesh. $1000 \mathrm{~g}$ of samples was filled and sealed in leakproof, air tight PVC merinelli beakers, weighed and stored for a period of four weeks to enable the samples to attain a state of secular equilibrium, where the rate of progeny becomes equal to that of the parent $\left(\mathrm{Ra}^{226} \text { and } \mathrm{Th}^{232}\right)^{[10]}$ and the system is calibrated using $\mathrm{Cs}^{137}$ and $\mathrm{Co}^{60}$ radioactive sources produce $\gamma$-ray energies of $662 \mathrm{KeV}, 1173 \mathrm{KeV}$ and $1332 \mathrm{KeV}$, respectively.

The spectrum was analysed by Leybold Cassy Lab MultiChannel Analyser model Pocket- CASSY 559901 (Germany made). The activity of $\mathrm{K}^{40}$ was estimated directly with1460.7 (10\%) KeV peak of the gamma ray spectrum. To determine the activity concentration of $\mathrm{Ra}^{226}$, the average value of gamma ray energies $295.1(19.2 \%)$ and 351.9 (37.1\%) $\mathrm{KeV}$ from $\mathrm{Pb}^{214}$ to 609.3 (46.1\%) and 1764.5 $(15.9 \%) \mathrm{KeV}$ gamma ray from $\mathrm{Bi}^{214}$ are used. The activity concentration of $\mathrm{Th}^{232}$ was determined using the average value of gamma rays peaks $238.6(43.6 \%) \mathrm{KeV}$ from $\mathrm{Pb}^{214}$, 338.4 (12\%),911.1 (29\%) and 968.9 (17.4\%) $\mathrm{KeV}$ from $\mathrm{Ac}^{228}, 583.1(86 \%)$ and $2614 \mathrm{KeV}$ from $\mathrm{Tl}^{208} \cdot{ }^{[11]}$ Each sample was examined for 18000 seconds. The Activity concentrations in the soil samples were calculated according to the following relation: ${ }^{[12,13,14]}$

$$
A=\frac{C}{\varepsilon \times P_{Y} \times M_{S} \times T}
$$

Where $\mathrm{C}$ is the count rate of gamma rays, $\varepsilon$ is the detectors efficiency of the specific $\gamma$-rays, $\mathrm{P}_{\gamma}$ is the absolute transition probability of the $\gamma$-decay, $M_{s}$ is the mass of the sample in $\mathrm{Kgs}$ and $\mathrm{T}$ is the counting time in seconds obtained for the measured radionuclides and are expressed in $\mathrm{Bq} \cdot \mathrm{Kg}^{-1}$ per dry weight.

\section{Absorbed dose rate in air}

In order to evaluate any radiological hazard, the exposure due to terrestrial radiations arising from radionuclides present soil can be estimated in terms of several parameters. A direct association between radioactivity concentrations of natural radionuclides and their exposure rate is known as the absorbed dose in the air at 1 meter above the ground surface. The average activity concentrations of $\mathrm{Ra}^{226}$ (of $\mathrm{U}^{238}$ series), $\mathrm{Th}^{232}$, and $\mathrm{K}^{40}\left(\mathrm{~Bq} \cdot \mathrm{kg}^{-1}\right)$ in soil samples are used to compute the absorbed dose rate given using the following relation provided by United Nations Scientific Committee on Effects of Atomic Radiations ${ }^{[13]}$ and European Commission. ${ }^{[15]}$ UNSCEAR and the European Commissions have provided the dose conversion coefficients for the typical room centers.

$\mathrm{D}\left(n G y h^{-1}\right)=0.462 \mathrm{~A}_{R a}+0.604 \mathrm{~A}_{T h}+0.0417 \mathrm{~A}_{K}$

Where $\mathrm{D}$ is the absorbed dose rate in $\mathrm{nGy} \cdot \mathrm{h}^{-1}, \mathrm{~A}_{\mathrm{ra}}, \mathrm{A}_{\mathrm{Th}}$, and $\mathrm{A}_{\mathrm{K}}$ are the activity concentration of $\mathrm{Ra}^{226}\left(\mathrm{U}^{238}\right), \mathrm{Th}^{232}$, and $\mathrm{K}^{40}$, respectively.

\section{Radiation Hazard Indices}

\section{External hazard index}

In order to bound the radiation exposure character of natural radionuclides present in the investigated samples to permissible dose equivalent limit of $1 \mathrm{mSv} \cdot \mathrm{y}^{-1}$, the $\mathrm{H}_{\mathrm{ex}}$ index based on a criteria have been incorporated by making use of a model Krieger which is given by: ${ }^{[16,17]}$

$\mathrm{H}_{e x}=\frac{\mathrm{A}_{\mathrm{Ra}}}{370}+\frac{\mathrm{A}_{\mathrm{Th}}}{259}+\frac{\mathrm{A}_{\mathrm{K}}}{4819} \leq 1$

To maintain the radiation hazard of no consequence, the value of $\mathrm{H}_{\mathrm{ex}}$ must not exceed the limit of one (unity). The maximum value of $\mathrm{H}_{\mathrm{ex}}$ equal to one corresponds to the upper limit of $\mathrm{Ra}_{\mathrm{eq}} 370$ Bq. $\mathrm{kg}^{-1[7]}$ measured dimensions and calculated densities.

\section{Radium equivalent activity}

The radium equivalent activity, $\mathrm{Ra}_{\mathrm{eq}}$, was incorporated to recognize the consistency to radiation exposure. The calculated values of $\mathrm{Ra}_{\mathrm{eq}}$ were usually used to evaluate the specific activity of materials containing diverse amounts of activity concentrations $\mathrm{U}^{238}, \mathrm{Th}^{232}$, and $\mathrm{K}^{40}$. Besides, $\mathrm{Ra}_{\mathrm{eq}}$ data can be used to assess the health hazard effects produced from the activity concentrations of $\mathrm{U}^{238}, \mathrm{Th}^{232}$, and $\mathrm{K}^{40}$ radionuclides in the studied soil samples. The calculated values of $\mathrm{Ra}_{\text {eq }}$ were obtained by the help of the following equation: $:^{[18,10]}$ 
$R a_{e q}\left(B q \cdot K g^{-1}\right)=A_{R a}+1.43 A_{T h}+0.077 A_{K}$

Where $A_{R a}, A_{T h}$, and $A_{K}$ are the specific activities of $\mathrm{Ra}^{226}$, $\mathrm{Th}^{232}$, and $\mathrm{K}^{40}$ respectively in Bq.kg). It is calculated based on the assumption that $370 \mathrm{~Bq} \cdot \mathrm{kg}^{-1}$ ) of $\mathrm{Ra}^{226}, 259 \mathrm{~Bq} \cdot \mathrm{kg}^{-1}$ of $\mathrm{Th}^{232}$, and $4810 \mathrm{~Bq} \cdot \mathrm{kg}^{-1}$ of $\mathrm{K}^{40}$ produce an equal gamma ray dose rate. Radium equivalent activity is straight forwardly related to the external and internal gamma dose due to radon and its progenies. ${ }^{[13]}$

\section{Annual effective dose equivalent}

The annual effective dose equivalent $\mathrm{E}_{\mathrm{T}}$ (AEDE) received by persons was estimated from the computed values of absorbed dose rate by applying the dose rate conversion factor of $0.7 \mathrm{~Sv} . \mathrm{Gy}^{-1}$ ) and the occupancy factors of $0.2 \times$ $(5 / 24)$ and $0.8 \times(19 / 24)$ for outdoors and indoors, respectively. ${ }^{[19]}$ The annual effective outdoor doses, $\mathrm{D}_{\text {out }}$; the annual effective indoor doses, $\mathrm{D}_{\text {in }}$; and total annual effective doses, $\mathrm{D}_{\text {tot }}$, were calculated according to the following equation. ${ }^{[20]}$

$D_{\text {our }}\left(m S v y^{-1}\right)=D_{r}\left(m G y h^{-1}\right) \times 24 h \times 365.25 d \times 0.2 \times 0.7 S v G y^{-1} \times 10^{-6}$

$D_{\text {in }}\left(m S v y^{-1}\right)=D_{r}\left(m G y h^{-1}\right) \times 24 h \times 365.25 d \times 0.8 \times 0.7 S v G y^{-1} \times 10^{-6}$

$D_{\text {tot }}\left(m S v Y^{l}\right)=D_{\text {out }}+D_{\text {in }}$

\section{Excess lifetime cancer risk}

It is a well-established fact that exposure ionizing radiations cause cancer in many diverse species of animals and in nearly all parts of the body. It is one of the few precisely established carcinogens in human beings, although it appears to be a relatively weak carcinogen compared to various chemical agents. The numerous years may go by between the radiation exposure and the manifestation of cancer.

The type of cancer that can be caused by exposure to radiation can also arise naturally (without increased exposure to radiation), but some occur more frequently as a result of exposure to radiations. For example, a higher percentage of small cell lung cancers occur in uranium miners as a result of exposure to alpha particle irradiation. Organs differ in their sensitivity to the effects of radiation. The thyroid gland and bone marrow are most sensitive to radiation, while the kidney, bladder, and ovary seem to be least affected. The cancer of blood forming cells (leukemia), a type of cancer that arises in the bone marrow; appear to be the most common radiation induced cancer. ${ }^{[20]}$

Radiation carcinogenesis is a most important stochastic effect, in human beings exposed occupationally to small doses of radiation. Human beings are always exposed to background radiation that arises both from natural and manmade sources. Natural radionuclides are omnipresent and when an ionizing radiation passes through a living tissue, it deposits energy in the tissue randomly and rapidly via excitation and ionization, in turn produces moving electrons. These electrons interact with atoms and molecules leading to chemical and molecular changes thereby altering the structure of the cells. These cells may be damaged directly by the radiation or indirectly by the free radicals $(\mathrm{OH}$ and $\mathrm{H})$ produced in the adjacent cells. Many forms of damage could occur from radiation but the most vital is that done to the deoxyribonucleic acid (DNA). A break to the DNA results in gene mutation, chromosomal aberration, breakages or cell death, oncogenic transformation and acute radiation sickness. More frequently, repairs can take place. This however depends on the condition that the damage is not a lethal damage. If mend is not faultless, it may result in a genetically modified cell. When human cells in an organ or tissue are killed or prevented from reproducing and functioning normally, there will be loss of organ function. A modified germ cell for instance in the gonads of an individual may transmit incorrect hereditary information, which may cause severe hereditary effects. Exposure to ionizing radiation over extended period is known to result in non- lethal mutation, which could increase the risk of cancer. ${ }^{[23]}$ There is a linear, no-threshold (LNT) association between radiation dose and the incidence of cancer. This dose-response hypothesis suggests that any increase in radiation dose, no matter how small, could results in an increase in cancer risk. Diseases caused by natural radiation exposure include lung cancer, pancreas, hepatic, skin, kidney cancers, cataracts, sterility, atrophy of the kidney and Leukemia. ${ }^{[2]}$

A radiation - induced cancer can grow from a single damaged cell autonomously of other damage cells in the tissue of interest. The period between radiation exposure and the recognition of cancer is known as the latent period and could be numerous years. Therefore, excess lifetime cancer risk is the chance that an individual will develop cancer over his/her lifetime of exposure.

The excess lifetime cancer risk (ELCR) values are calculated using the equation. ${ }^{[6,12]}$

$E L C R=D_{\text {in }} \times D_{L} \times R_{F}$

Where $\mathrm{D}_{\mathrm{L}}$ is the length of life (approximately 70 years), and $\mathrm{R}_{\mathrm{F}}$ is the risk factor $\left(\mathrm{Sv}^{-1}\right)$, which reflects the fatal cancer risk per Sievert. For Stochastic effects, ICRP 60 uses values of 
0.05 for the public. ${ }^{[25,26]}$

\section{RESULTS}

The radioactivity concentration of $\mathrm{Ra}^{226}, \mathrm{Th}^{232}$, and $\mathrm{K}^{40}$ in soil samples of the lignite belt and in the soil of the villages surrounding the lignite belt are presented in the Tables $1 \& 2$ respectively. The $\mathrm{Ra}^{226}$ was distinctly higher than $\mathrm{Th}^{232}$ and $\mathrm{K}^{40}$ with mean activity $52.9 \mathrm{~Bq} \cdot \mathrm{Kg}^{-1}$ in the soil of the lignite belt. The $\mathrm{Th}^{232}$ activity concentration ranges from 18.3 to 24.0 Bq. $\mathrm{Kg}^{-1}$ with mean activity $22.5 \mathrm{~Bq} \cdot \mathrm{Kg}^{-1}$ which are less than the activity concentration of $\mathrm{K}^{40}$ as reported in the Table 1. The activity concentrations of the soil of the villages surrounding the lignite belt reported in the Table 2 shows higher value compared to the activity concentration of the soil of the lignite belt. The value of $\mathrm{Ra}^{226}$ activity concentration ranges from 51.6 to 61.8 with mean value 56.6 Bq. $\mathrm{Kg}^{-1}$. The $\mathrm{Th}^{232}$ and $\mathrm{K}^{40}$ activity concentration have the mean values 75.0 and $40.70 \mathrm{~Bq} . \mathrm{Kg}^{-1}$ respectively. For comparison purpose, the activity concentration of $\mathrm{Ra}^{226}$, $\mathrm{Th}^{232}$, and $\mathrm{K}^{40}$ has been compared with the published data reported by the different nations (Table3), the observed mean values of $\mathrm{Ra}^{226}$ and $\mathrm{Th}^{232}$ are higher than the world average. While as the average values of $\mathrm{K}^{40}$ was well below the world average. ${ }^{[13]}$ The $\mathrm{Ra}_{\mathrm{eq}}$ activity a relevant quantity for when considering radiation risk to humans were estimated using the Equation (4) for all the soil samples and other radiological hazard indices determined are summarized in the Tables1\&2. The gamma absorbed rate in air at a height of $1 \mathrm{~m}$ above the ground due to concentrations of $\mathrm{Ra}^{226}, \mathrm{Th}^{232}$ and $\mathrm{K}^{40}$ in the soil of the lignite belt and soil of the villages surrounding the lignite belt, estimated by the using Equation (2), is presented in the respective tables. The external hazard index is also presented in the tables for both the types of the samples.

As shown in Tables $1 \& 2$, the excess life time cancer risk, determined for soil of the lignite belt and the soil of the villages surrounding the belt, ranged from $0.65 \times 10^{-3}$ to $0.71 \times 10^{-3}$ with an average of about $0.68 \times 10^{-3}$ for the soil of the lignite belt and $1.15 \times 10^{-3}$ to $1.34 \times 10^{-3}$ with an average of $1.25 \times 10^{-3}$ for the soil of the villages surrounding the belt.

\section{DISCUSSION}

The radionuclide concentrations for the two different classes of soil samples under investigation indicate and envisage the disagreement of geological formation for the area under study. Soils are considered as weathered byproducts of rock types and circulation of radioactive elements is enormously affected by natural processes like weathering, rainfall of a place and erosion. Soil radioactivity depends mainly on the types of rocks from which the soil originates.

The mean value of absorbed dose rate due to soil of the lignite belt and due soil of the villages surrounding the belt are 39.5 and73.1 nGy. $\mathrm{h}^{-1}$ respectively. The absorbed rate estimated from soil for the Indian sub-continent is about $69.0 \mathrm{nGy} \cdot \mathrm{h}^{-1[12]}$ and the world average is $51.0 \mathrm{nGy} \cdot \mathrm{h}^{-1} .^{[10]} \mathrm{In}$ the present study the average absorbed dose rate due soil of the villages surrounding the lignite belt is higher than the global value. The annual effective dose rate ranges from 0.04 to $0.05 \mathrm{mSv}^{-1} \mathrm{y}^{-1}$ with mean value of $0.05 \mathrm{mSv} \cdot \mathrm{y}^{-1}$ for the soil of the lignite belt and 0.08 to $0.1 \mathrm{mSv} \cdot \mathrm{y}^{-1}$ with an average value of $0.09 \mathrm{mSv} \cdot \mathrm{y}^{-1}$ for the soil of villages surrounding the lignite belt respectively. The mean value annual effective dose rates for the soil of the villages surrounding the lignite belt are higher than the value $0.07 \mathrm{mSv}^{-1} \mathrm{y}^{-1}$ given by $\mathrm{UNSCEAR}^{[13]}$ as the world wide representative value.

Radiation induced cancer being a stochastic effect may appear only some years after the irradiation and the likelihood of occurrence increases with increasing absorbed dose and there is no threshold. Radium being a solid radioactive element is chemically similar to calcium, and is absorbed from soil by plants and conceded up the food chain to humans. Microscopic quantities of radium in the environment can lead to some accumulation of radium in bone tissue whereby it degrades bone marrow and can mutate bone cells. Ingestion or body exposure to radium causes serious health effects which included sores, anemia, bone cancer and other disorders. $\mathrm{Ra}^{226}$ is a product of $\mathrm{U}^{238}$ decay series. Emitted energy from the decay of radium causes vexed on the skin and produces many other detrimental effects. Radium is a naturally occurring radioactive metal moreover it is present in soil, sand, rock, water, plants and animals. Higher values of radium in sand contribute significantly in the enhancement of indoor radon in dwellings. ${ }^{[17]}$ Radium is one million times more radioactive than the same mass of uranium. Its decay occurs in at least seven stages, the following main products were called radium emanation recognized as radon. Radon is a heavy gas and the later products are solids. These products are themselves radioactive in nature. Radon is the first leading cause of lungs cancer among non smokers and second leading cause in smokers.

In order to find the dependence of excess life time cancer 
Table 1:Activity concentration of $\mathrm{R}^{226}, \mathrm{Th}^{232}, \mathrm{~K}^{40}$, Radium equivalent activity, radiological hazard indices and excess life time cancer risk for the soil of lignite belt.

\begin{tabular}{|c|c|c|c|c|c|c|c|c|}
\hline $\begin{array}{l}\text { Sample } \\
\text { code }\end{array}$ & \multicolumn{3}{|c|}{$\frac{\text { Activity }}{\text { Concentration }}$} & $\begin{array}{c}\mathrm{Ra}_{\mathrm{eq}} \\
\left(\mathrm{Bq} \cdot \mathrm{Kg}^{-1}\right)\end{array}$ & $\begin{array}{l}\text { Absorbed } \\
\text { Dose } \\
\text { rate } \\
\left(\mathrm{nGy} \cdot \mathrm{h}^{-1}\right)\end{array}$ & $\mathrm{H}_{\mathrm{ex}}$ & $\begin{array}{c}\mathrm{E}_{\mathrm{T}} \\
\left(\mathrm{mSv} \cdot \mathrm{y}^{-1}\right)\end{array}$ & ELCR X $10^{-3}$ \\
\hline $\mathrm{S}_{1}$ & 53.6 & 23.4 & 39.8 & 90.1 & 40.6 & 0.2 & 0.05 & 0.70 \\
\hline $\mathrm{S}_{2}$ & 53.9 & 24.0 & 39.8 & 91.3 & 41.1 & 0.3 & 0.05 & 0.71 \\
\hline $\mathrm{S}_{3}$ & 52.7 & 23.4 & 27.8 & 88.3 & 39.6 & 0.2 & 0.05 & 0.68 \\
\hline $\mathrm{S}_{4}$ & 53.2 & 22.5 & 35.8 & 88.1 & 39.7 & 0.2 & 0.05 & 0.68 \\
\hline $\mathrm{S}_{5}$ & 55.2 & 18.3 & 27.8 & 83.5 & 37.7 & 0.2 & 0.05 & 0.65 \\
\hline $\mathrm{S}_{6}$ & 55.4 & 21.3 & 26.2 & 87.9 & 39.6 & 0.2 & 0.05 & 0.68 \\
\hline $\mathrm{S}_{7}$ & 46.0 & 22.1 & 30.1 & 79.9 & 35.9 & 0.2 & 0.04 & 0.62 \\
\hline $\mathrm{S}_{8}$ & 55.6 & 23.0 & 32.3 & 91.0 & 40.9 & 0.3 & 0.05 & 0.70 \\
\hline $\mathrm{S}_{9}$ & 52.3 & 24.0 & 38.7 & 89.6 & 40.3 & 0.2 & 0.05 & 0.69 \\
\hline $\mathrm{S}_{10}$ & 51.2 & 23.6 & 31.6 & 87.4 & 39.2 & 0.3 & 0.05 & 0.67 \\
\hline Mean & 52.9 & 22.5 & 33.0 & 87.7 & 39.5 & 0.2 & 0.05 & 0.68 \\
\hline SD & 2.8 & 1.7 & 5.2 & 3.5 & 1.6 & 0.01 & 0.002 & 0.027 \\
\hline Median & 53.4 & 23.2 & 33.0 & 88.3 & 39.7 & 0.24 & 0.05 & 0.68 \\
\hline
\end{tabular}

Table 2: Activity concentration of $\mathrm{R}^{226}, \mathrm{Th}^{232}, \mathrm{~K}^{40}$, Radium equivalent activity, radiological hazard indices and excess life time cancer risk for the soil of villages surrounding the lignite belt.

\begin{tabular}{|c|c|c|c|c|c|c|c|c|}
\hline \multirow[t]{2}{*}{$\begin{array}{l}\text { Sample } \\
\text { code }\end{array}$} & \multicolumn{3}{|c|}{$\frac{\text { Activity Concentration }}{\left(\mathrm{Bq} \cdot \mathrm{Kg}^{-1}\right)}$} & \multirow[t]{2}{*}{$\begin{array}{c}\mathrm{Ra}_{\mathrm{eq}} \\
\left(\mathrm{Bq} \cdot \mathrm{Kg}^{-1}\right)\end{array}$} & \multirow{2}{*}{$\begin{array}{c}\text { Absorbed } \\
\text { Dose } \\
\text { rate }\left(n G y \cdot h^{-1}\right)\end{array}$} & \multirow[t]{2}{*}{$\mathrm{H}_{\mathrm{ex}}$} & \multirow[t]{2}{*}{$\begin{array}{c}\mathrm{E}_{\mathrm{T}} \\
\left(\mathrm{mSv}^{-1} \mathrm{y}^{-1}\right)\end{array}$} & \multirow[t]{2}{*}{ ELCR X $10^{-3}$} \\
\hline & $\mathrm{R}^{226}$ & $\mathrm{Th}^{232}$ & $\mathrm{~K}^{40}$ & & & & & \\
\hline $\mathrm{VS}_{1}$ & 52.0 & 68.9 & 37.4 & 153.4 & 67.2 & 0.4 & 0.08 & 1.16 \\
\hline $\mathrm{VS}_{2}$ & 51.6 & 68.3 & 38.2 & 152.2 & 66.7 & 0.4 & 0.08 & 1.15 \\
\hline $\mathrm{VS}_{3}$ & 55.7 & 73.7 & 46.1 & 164.6 & 72.2 & 0.4 & 0.09 & 1.24 \\
\hline $\mathrm{VS}_{4}$ & 58.8 & 77.9 & 41.3 & 173.4 & 75.9 & 0.5 & 0.09 & 1.31 \\
\hline $\mathrm{VS}_{5}$ & 57.2 & 75.8 & 39.8 & 168.7 & 73.9 & 0.5 & 0.09 & 1.27 \\
\hline $\mathrm{VS}_{6}$ & 55.1 & 72.9 & 39.3 & 162.4 & 71.1 & 0.4 & 0.09 & 1.27 \\
\hline $\mathrm{VS}_{7}$ & 61.8 & 81.8 & 38.8 & 181.8 & 79.6 & 0.5 & 0.1 & 1.22 \\
\hline $\mathrm{VS}_{8}$ & 58.0 & 76.9 & 44.8 & 171.4 & 75.1 & 0.5 & 0.09 & 1.29 \\
\hline $\mathrm{VS}_{9}$ & 55.5 & 73.5 & 41.7 & 163.8 & 71.8 & 0.4 & 0.09 & 1.23 \\
\hline $\mathrm{VS}_{10}$ & 60.0 & 80.3 & 39.8 & 177.9 & 77.9 & 0.5 & 0.1 & 1.34 \\
\hline Mean & 56.6 & 75.0 & 40.7 & 167.0 & 73.1 & 0.5 & 0.09 & 1.25 \\
\hline $\begin{array}{c}\text { Standard } \\
\text { Deviation }\end{array}$ & 3.3 & 4.4 & 2.8 & 9.7 & 4.2 & 0.03 & 0.005 & 0.062 \\
\hline Median & 56.45 & 74.8 & 39.8 & 1.6 & 73.0 & 0.45 & 0.09 & 1.24 \\
\hline
\end{tabular}

Table 3: The average value of concentrations of the natural radionuclides in soil samples Bq. $\mathrm{Kg}^{-1}$ reported for different parts of world.

\begin{tabular}{|c|c|c|c|c|}
\hline Country & \multicolumn{3}{|c|}{ Mean Activity Concentration (Bq. Kg } & Reference \\
\cline { 2 - 5 } & $\mathrm{R}^{226}$ & $\mathrm{Th}^{232}$ & \\
\hline Egypt & 18.7 & 24.7 & 331.0 & 27 \\
\hline Japan & 32.4 & 54.0 & 794.0 & 28 \\
\hline Taiwan & 30.0 & 44.0 & 431.0 & 28 \\
\hline Ireland & 37.0 & 26.0 & 350.0 & 28 \\
\hline Turkey & 79.0 & 62.0 & 574.0 & 29 \\
\hline Venezuela & 27.0 & 31.0 & 357.0 & 30 \\
\hline Bangladesh & 33.0 & 16.0 & 574.0 & 31 \\
\hline Southern Punjab Pakistan & 21.7 & 31.0 & 393.2 & 32 \\
\hline Indian Punjab & 56.74 & 87.42 & 143.04 & 19 \\
\hline Lahore Pakistan & 25.8 & 49.2 & 561.6 & 9 \\
\hline Punjab Province Pakistan & 58.23 & 53.6 & 564.48 & 33 \\
\hline Indian Average & 16.0 & 37 & 100.0 & 17 \\
\hline World Average & 50.0 & 50.0 & 500.0 & 13 \\
\hline soil of Lignite Belt & 52.9 & 22.5 & 33.0 & Present Study \\
\hline $\begin{array}{c}\text { Soil of Villages Surrounding } \\
\text { the lignite Belt }\end{array}$ & 56.6 & 75.0 & 40.7 & Present Study \\
\hline
\end{tabular}


risk on the activity concentration and the dependence of excess life time cancer risk with other radiological hazard indices, correlation analysis was performed between the $R a_{e q}$ and excess life time cancer risk and measured dose rate and excess life time cancer risk Figures $2 \& 3$ for both types of the soil. A very strong correlation was observed between the $\mathrm{Ra}_{\mathrm{eq}}$ and excess lifetime cancer risk $(\mathrm{r}=1)$ and between measured dose rate and excess life time risk of cancer $(\mathrm{r}=1)$ for the soil of the lignite belt compared to the correlation between the $\mathrm{Ra}_{\mathrm{eq}}$ and excess life time cancer risk ( $\mathrm{r}=0.73$ ) and between measured dose rate and excess life time cancer risk $(r=0.74)$ for the soil of the villages surrounding the lignite belt. The average value of excess life time risk of cancer determined for both the soil types is present study is higher than the world average of $0.29 .{ }^{[27]}$ Radiation induced cancer is probabilistic in nature and there is no threshold for it. Hence all doses carry some form of risk. Hence radiation induced cancer cannot be prevented, only can be reduced by minimizing the radiation dose.

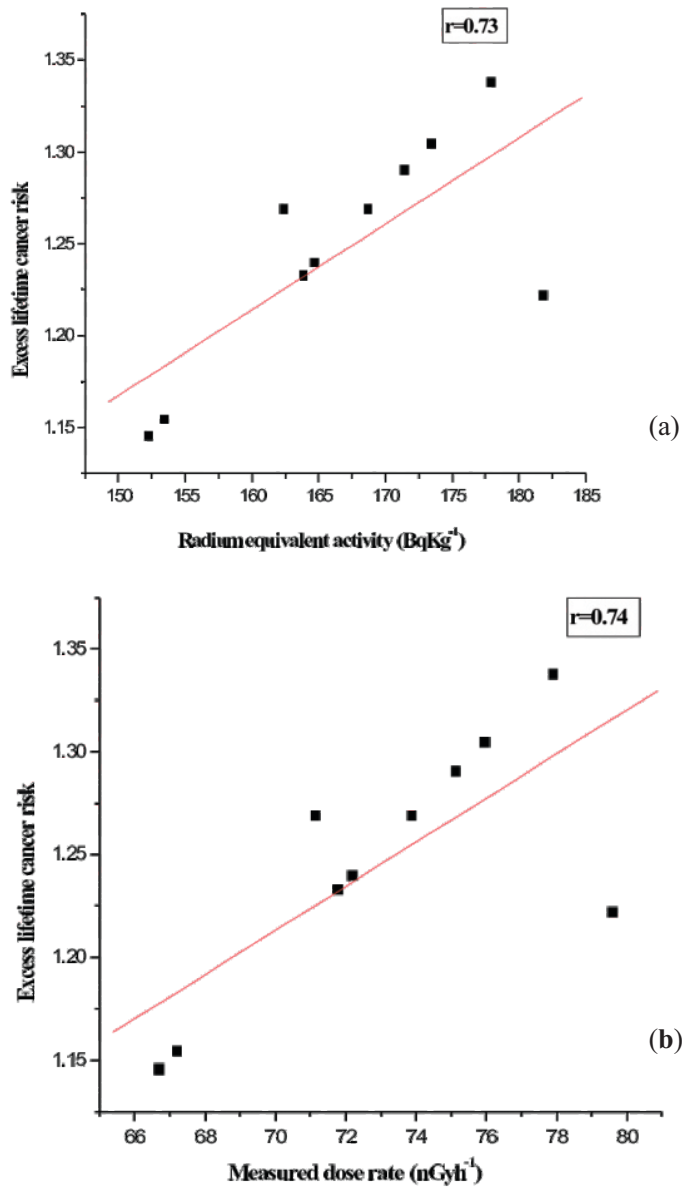

Figure 2:Correlation between excess life time cancer risk and (a) radium equivalent activity and (b) measured dose for the soil of the villages surrounding the lignite belt.
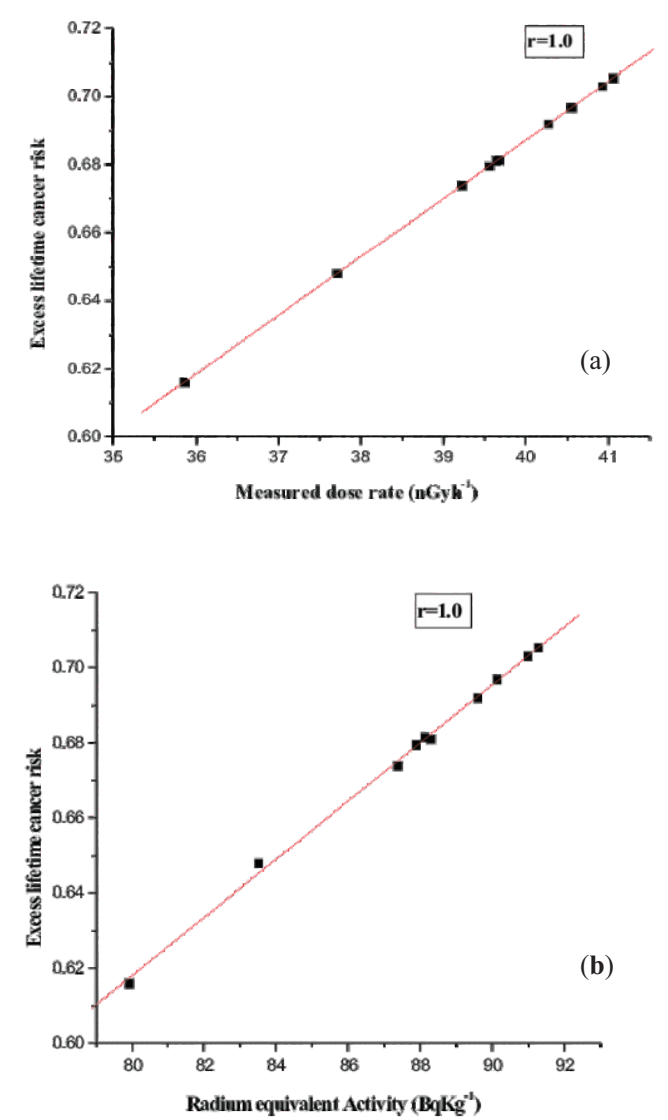

Figure 3:Correlation between excess life time cancer risk and (a) radium equivalent activity and (b) measured dose for the soil of the lignite belt.

\section{CONCLUSION}

The measurement of activity concentrations for primordial radionuclides in the soil of the lignite belt and the soil ofthe villages surrounding the lignite belt have been carried out by using a $\mathrm{Pb}$ - shielded $\mathrm{NaI}(\mathrm{Tl})$ gamma ray spectrometer in order to evaluate the associated radiological health hazards with an intention that this study will serve as the baseline data for carrying out the extensive research in the area. The activity concentrations of the soil of the villages surrounding the lignite belt reported in the table 2 shows higher value compared to the activity concentration of the soil of the lignite belt table 1 . The radionuclide concentrations for the two different classes of soil samples under investigation indicate and envisage the disagreement of geological formation for the area under study. The observed mean values of $\mathrm{Ra}^{226}, \mathrm{Th}^{232}$ are greater than the world average while as the average values of $\mathrm{K}^{40}$ is well below the world average. The mean value of absorbed dose rate due to soil of the lignite belt and due soil of the villages 
surrounding the belt are 39.5 and $73.1 \mathrm{nGyh}^{-1}$ respectively.

The average value of excess life time risk of cancer determined for both the soil types in the present study is higher than the world average of 0.29. ${ }^{[2]}$ Further the correlation analyses performed between the radium equivalent activity and excess life time cancer risk for the two types of the sample show very strong and linear dependence of excess life time cancer risk on radium equivalent activity and measured dose rate for the soil of the lignite belt compared to the soil of the villages surrounding the lignite belt.

\section{References}

1. March H C, 1994 Radiology 43275.

2. Hacker B C, 1987 The dragon's tail, University of California Press 1942-1946

3. Schull W J,1995 Effects of atomic radiation New York: Wiley-Liss.

4. Isinkaye O M, Jibiri N N, Olomide A A, $2015 \mathrm{~J}$. Med. Phys. 40, 52

5. Maharana M, Krishnan N, Sengupta D, $20142015 \mathrm{~J}$. Med.Phys.35, 235

6. Mudasir A, Anu Radha C, Shakeel A, Sajad M, Rayees A D, Ramasubramanian V, 2016 Radiochimica Acta, 104(9); 673-680

7. Mudasir A, Anu Radha C, Shakeel A, Sajad M, Rayees AD, et al., 2016 Radiochimica Acta, 104(6); 435-444

8. Geology and mineral resources of Jammu and Kashmir, 2004 Geol. Surv. Ind. Misc. Pub.30(X)

9. Akhter N, Tufail M, Ashraf M, Iqbal M M, 2005 Radiat. Meas.39, 11-14.

10. Akkurt I, Oruncak B, and Gunoglu K, 2010 Int J Phys Sci.5,170

11. Debertin K, and Helmer G, 1988 North-Holland, Amsterdam

12. Beretka J, Mathew PJ, 1985 Health Phys.48, 87

13. United Nations Scientific Committee on Effects of Atomic Radiation (UNSCEAR), 2000 Report to the General Assembly, Annexure B

14. Issa S A, 2013 Radiat Prot Dosimetry, 156(1): 59-67.

15. European Commission(EC), 1999 Journal of Nuclear Safety and Civil Protection.

16. Alharabi W, Al Zahrani J, Abbady A,2011 Austr J Basic Sci.672
17. Singh S, Rani A, Mahajan R K, 2000 Radiat. Meas.39, 431

18. Pooja C, and Rishi P C,2014 J Envir Health Sci and Engg, 12, 70

19. Abdel G H,2010 Am Env Sci, 6,90

20. Taskin H, Karavus M, Ay P, Topuzoglu A, Hindiroglu S, and Karahan G, 2009 J. Environ. Rad.100, 49-53

21. Sevc J, Kunz E, Placek V, 1976 Health Physs. 30(6), 433

22. Karahan G, 2010 Radiat Prot Dosimetry, 142(24):324-31.

23. Brenner J D, Sachs K R, 1976 Radiation Environ Biology, 44, 253-25

24. Jablon S, Tachikawa K, Belsky J L, and Steer A, 1971 Lancet $\mathbf{1 , 7 7 0 6}$

25. International Commission On Radiation Protection (ICRP), 1977 pergamon Press, Oxford, New York, Frankfurt, Publication 26

26. United Nations Scientific Committee on Effects of Atomic Radiation (UNSCEAR), 1993 Report to the General Assembly, Annexure B

27. Ebaid Y Y, El-Taha M S, El-Kakary A A, Garcia S R, and Brooks G H,2000 J. Radioanal. Nucl. Chem. 243, 543

28. Selavasekarapandian S, ShivakumarR., Manikandaram N M, Meenakshisundaram, V, et al., 2000 Appl. Radiat. Isotop.52, 299

29. Bayakara, O, Do־gru M, 2009 Radiat.Meas. 44, 116

30. La Breque J J, 1998. J. Radioanal. Nucl. Chem. 178, 327

31. Miah F K, Roy S, Touhiduzzaman M, and Alam B, 1998 Appl. Radiat. Isotop. 49, 13

32. Fatima I, Zaidai J H, Arif M, Daud, M M, Ahmad S A, and Tahir S NA, 2008 Radiat. Prot. Dosim. 128, 206

33. Rehman S U, Matiullah Malik F, Rafique M, Anwar J, Ziafa M, and Jabbar A, 2011 J. Radioanal. Nucl. Chem. 287, 647 